\title{
Male and female language teachers' technology integration differences in elementary schools in the United Arab Emirates
}

\author{
Almekhlafi, Abdurrahman Ghaleb \\ United Arab Emirates University, United Arab Emirates (almekhlafi@uaeu.ac.ae) \\ Ismail, Sadiq Abdulwahed \\ United Arab Emirates University, United Arab Emirates (isadiq@uaeu.ac.ae)
}

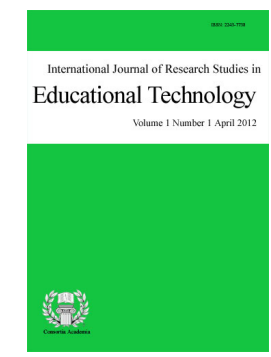

ISSN: $2243-7738$ Online ISSN: 2243-7746

OPEN ACCESS

Al-Mekhlafy, Mohamed Hatem

Sana'a University, Yemen (mhatemalm@gmail.com)

\section{Abstract}

Today, educators and policy makers are paying increasing attention to the integration of educational technology in K-12 schools to promote better learning outcomes. Research has recently indicated that integrating technology into the curriculum promotes not only stimulating curricula based on real world problems and tools, but it also expands opportunities for successful teaching and learning. Teachers have found technology to be a motivating and appealing tool in their classes, particularly when it comes to teaching languages. However, investigating the differences between male and female teachers pertaining to technology integration strategies and applications has not received enough attention, particularly in elementary schools in the United Arab Emirates (UAE). The purpose of this study was to investigate the differences between male-female teachers' technology integration in elementary schools in the UAE. A Questionnaire and focus group interviews were used as the two main tools for data collection. Results show some significant differences between male and female teachers in the strategies and intensity of technology integration in their classes. Both quantitative and qualitative results show that teachers perceived technology as a tool for promoting language teaching and learning. Recommendations for successful technology integration were highlighted at the end of the study. Suggestions for conducting further studies were also discussed.

Keywords: technology integration; gender; EFL/ESL; male and female teachers 


\section{Male and female language teachers' technology integration differences in elementary schools in the United Arab Emirates}

\section{Introduction}

The growing advancement in technology and its popularity in other disciplines have drawn the attention of different people such as policy makers and educators in different countries worldwide, including the UAE. Kanthawongs, Penjuree, Kanthawongs, and Penjira (2013) indicated that students, parents and teachers should prepare themselves for this advancement. Thus, a number of researchers in different parts of the world conducted different studies to investigate the impact and/or effectiveness of integrating technology in education. For example, Badia, Menesesa, Sigalésa, and Fàbregues (2014) indicated that there are potential benefits of digital technology for teaching and learning in schools that have been extensively characterized in the academic literature. The common theme of most of these studies highlighted the effectiveness of implementing technology to facilitate and improve learning and teaching (Frigaard, 2002; Schofield \& Davidson, 2003; Timucin, 2006; Roblyer \& Davis, 2008; Tømte, 2008; Yukselturk \& Cakir, 2011; Thang et al., 2016; Razavi, Ghanizadeh, \& Akbari, 2016).

However, successful integration of technology in education depends heavily on the views and willingness of people involved in its employment to enhance teaching and learning. Although schools often incorporate a variety of technologies, technology use in the schools still falls short to answer 21 st century students' learning needs, particularly in developing countries (Karaca, \& Yildirim, 2013). For instance, Nikian, Nor, and Aziz (2013) found that some teachers are still resisting the use of technology in their classrooms. In addition, such implementation should not be hindered by the common obstacles to technology integration such as knowledge, skills, confidence, access, time, and many others. (Banas, 2010).

Teachers' attitudes towards using information and communications technologies in their respective classrooms are a key factor in facilitating successful technology integration (Bitner \& Bitner, 2002). Furthermore, several studies found significant positive relationships between perception of teachers and their computer use level (Kobak \& Taskin; 2012; Korumaz \& Karabiyik, 2014; Hüseyin, 2014; Yastibas \& Cepik, 2015; Yungwei \& Lee, 2015; Rafieea \& Purfallah, 2014; Kavanoz Yüksel, \& Ozcan, 2015). The successful results of the uses of technology in the education sector have recently encouraged decision makers and educators to allocate more budget to introduce and utilize sophisticated devices to improve learning outcomes.

In the UAE today, technology is seen as an integral part of the school curriculum. In a study within the UAE's context, Ismail, Almekhlafi, and Almekhlafy (2010) reported that teachers' views of the role of technology in teaching and learning both Arabic and English were very positive in spite of the existing of barriers such as limited access to such devices especially in private schools and remote areas, lack of training, experience, etc. The researchers concluded that teachers are very much willing to use technology in their classes if they are provided with incentives and unlimited access to technology such as computers and the Internet. Similarly, Saqlain, Al-Qarni, and Ghadi (2013) found that all the participating teachers of their study were willing to use technology to teach English as a foreign language. The issue of differences between males' and females' attitudes and perceptions regarding the use of technology was highlighted in the aforementioned study as an important research topic to be investigated by a further study in the future.

This study investigates the differences between male and female language teachers' perceptions of technology integration, types of technology used, barriers impeding such use, and technology effectiveness for promoting language learning and teaching in K-12 schools in the UAE. By addressing this issue, a better understanding of the gender gap in technology integration perceptions can be reached and solutions for closing this gap can be studied in subsequent studies. 
Male and female language teachers' technology integration differences in elementary schools in the UAE

This study will contribute to the existing literature in the area of integrating technology in teaching languages in general and ESL/EFL in particular. This is, especially true in the Gulf Countries region (e.g. the United Arab Emirates, Saudi Arabia, Kuwait, and many others.) as very limited studies have been conducted on the same specific issue.

\section{Literature review}

The topic of gender differences in the utilization of technology in teaching and learning has drawn the attention of a number of researchers and educators in different countries. A number of studies have investigated technology integration in different settings and levels, including k-12 classrooms. Among these studies are the ones investigating technology integration differences between male and female teachers (Kumar et al., 2008; Almekhlafi \& Almeqdadi, 2010).

In their study, Kumaret et al. (2008) referred to some studies on gender differences in computer technology adoption and usage and they summarized some of their findings. They pointed out that some researchers considered gender to be the main factor in their investigation of technology use. Similarly, Almekhlafi and Almeqdadi (2010) pointed out that many studies in the literature showed some differences between male and female teachers in technology use. On the other hand, other studies did not show much difference. Various studies conducted in the $80 \mathrm{~s}$ and $90 \mathrm{~s}$ as well as recently conducted studies showed different results; sometimes favoring males and at other times favoring females, and sometimes not favoring either of them as will be discussed below.

\subsection{No significant difference studies}

As mentioned above, some studies conducted on gender differences using technology did not show any significant differences between males and females in computer use and computer applications (Smith, 1986; Woodrow, 1991; Gattiker \& Hlavka 1992; Sia 2000; Mehloff, 2001; Wong \& Hanafi, 2007; Top, Yukselturk, \& Cakir, 2011; Bakr, 2011).

According to Smith (1986), computer skills acquired in a carefully structured learning experience, gender differences were not significant. Similarly, Woodrow (1991); Sia (2000); and Mehloff (2001) reported that there were no significant differences in the mean scores of using computers based on gender. Following the same path, Gattiker and Hlavka (1992) found no gender differences when comparing attitudes of computer owners. The decision to own a computer was viewed as self-socialization.

Wong and Hanafi (2007) investigated the attitudes of 73 female and 29 male student teachers in Universiti-Putra Malaysia toward IT before and after undergoing an IT course. The results did not show any significant differences between female and male student teachers. Both showed the same levels of attitudes before and after taking the IT course. The authors indicated that this finding suggested that IT did not have any significant gender disparity. Similarly, a study conducted in Nigeria by Onwuagboke and Singh (2016) about the use of ICT in teaching and the attitude of male and female teachers in three tertiary institutions reported no significant differences in relation to gender.

A few recent studies also documented such insignificant differences (e.g., Top, Yukselturk \& Cakir, 2011; Bakr, 2011). Top, Yukselturk and Cakir (2011) looked at gender differences in ICT teachers' usage of Web 2.0 applications with respect to their awareness components (actual behavior, attitude, ease of use, perceived usefulness, perceived behavioral control, and compatibility and self-efficacy). They reported no significant difference in the usage of Web 2.0 applications.

Similar findings were reported by Bakr (2011), who investigated 118 Egyptian public school teachers' attitudes towards computers in terms of gender and years of teaching experience. Findings showed that the teachers' attitudes towards computers were positive. In addition, there were no significant differences in terms of 
gender and teaching experience. The author pointed out that the findings of this study indicated that teachers' attitude towards computers at government-schools is relatively high and that no significant gender difference is existing among them. The author concluded that this suggested that both Egyptian male and female teachers in government-schools have the same perceptions about computers.

\subsection{Significant difference studies}

The rapid development in information technology has encouraged a number of researchers to investigate teachers' perceptions toward the expansion of educational technology and its integration in teaching and learning. Some research, for example, has shed light on the issue of gender and its impact on teaching and learning. A number of research studies reported a significant difference between male and female use of technology in general and computer in particular (Lee, 1997; Ray, Sormunen, \& Harris, 1999; Venkatesh \& Morris, 2000; Houtz \& Gupta, 2001; Hong \& Koh, 2002; Astrid, 2002; Martina, Meelissen, \& Drent, 2008; Ozer, Ugurlu, \& Beycioglu, 2011; Bakr, 2011).

Venkatesh and Morris (2000) identified significant difference between females and males in introducing a system for information retrieval. They found that men put more emphasis on perceived usefulness in determining behavioral intention to use, while women regarded perceived ease of use as a more significant factor in determining behavioral intention to use.

Other studies on technology integration pertinent to gender differences show more or less similar results as the earlier research studies. Studies by Lee (1997), Houtz and Gupta (2001), and Yuen and Ma (2002) showed that there is a strong relationship between gender and actual employment of computers. While, Ray, Sormunen, and Harris (1999) in their comparative study about the attitude of men and women toward computer concluded that females are more positive about computers than males. In another study, Hong and Koh (2002) indicated that female teachers were more anxious than their counterpart male teachers towards hardware. However, the overall computer anxiety levels were not significantly different between male and female teachers.

In a similar study conducted by Astrid (2002), males demonstrated positive perceptions towards computers as well as higher confidence in their own success more than females. The finding of this research suggested that females' attitudes are influenced by families, schools and the larger culture to limit their access to use computers to serve their purposes. It also indicated that attitude can be an outcome of previous computer experience. Hence, experience with computers is necessary for a more positive attitude towards computers, yet a positive attitude is necessary in order to engage students in working with computers.

Within the same direction, Broos (2005) reported that males were more enthusiastic to develop a more positive attitude toward a new medium of communication such as the Internet. On the other hand, females take longer time to become familiar and consequently take longer time to develop positive feelings for new technology. In addition, according to Broos (2005), it was found that prior computer experience would only have a positive effect on males. More experienced male users showed greater positive attitudes toward IT while females with equal computer experience reported having computer anxiety.

Other researchers, such as Ilie et al. (2005), also pointed out that a number of research studies have found that users' perceptions revealed willingness to use technology, and that their perceptions tend to differ based on gender. Researchers pointed out that many studies have shown that male students have positive attitudes more than female students do and on the other hand, other fewer studies showed that women have positive attitudes more than men do.

Some research has focused on the issue of gender in relation to other variables such as experience, amount of use, type of use, and interest in computers. Johnson (2006) stated that the New Zealand government has increasingly promoted computer use within schools through policy and through the provision of computers and professional development, amongst other initiatives. These trends in New Zealand are similar to those seen in 
Male and female language teachers' technology integration differences in elementary schools in the UAE

other developed countries. The study findings showed fewer differences between the use of computers by girls and boys. However, perceptions of computer expertise were very relevant to gender. Although, overall results reported that neither gender was better at using computers, computer expert students were found to be boys within each class.

According to Meelissen and Drent (2008), research on gender differences in ICT has shown that in most countries (including the Netherlands) females are often behind males in ICT use and ICT knowledge and skills. In addition, in a recent study, Gibbs and Bernas (2010) reported that gender disparities exist in online communication. Gender disparities were found in communication styles and in the use of socio-emotional contents. According to the researchers, men were expository whereas messages posted by women were of an 'epistolary' nature. Women used socio-emotional content more than men did. However, interactions, such as the extent to which men and women persisted in message threads as well as responded to one another were overall comparable. Nevertheless, women posted more messages of longer nature, but men received more replies to their messages. Two studies conducted recently (Ozer, Ugurlu, \& Beycioglu, 2011; Bakr, 2011) showed that differences existed between males and females in their attitudes toward computer use. Ozer, Ugurlu, and Beycioglu (2011) reported differences in girls' and boys' attitudes towards the experience with the amount of use, type of use and interests in computers. Results show that the opinions of male and female teachers are significantly different.

In spite of the different and inconsistent research findings in relation to gender differences, Yukselturk and Bulut (2009) reported that the gender gap in ICT areas has been narrowed over the past several years. Top, Yukselturk and Cakir (2011) found that a greater number of females than males started using the Internet and Web 2.0 technologies, such as weblogs, wikis, podcasts and social networks. However, the researchers reported no significant difference in the usage of Web 2.0 applications. Male teachers' scores on their views about perceived behavioral control and self-efficacy were found to be significantly higher than those views of the female teachers. Moreover, self-efficacy variable explained a significant amount of variance in female teachers' use of Web 2.0 applications and two variables (actual usage/behavior and compatibility) showed a significant amount of variance in male teachers' use of Web 2.0 applications.

This could be because teachers are trying to integrate these technologies into the teaching and learning environments because of their growing benefits, such as accessibility, usability, functionality and flexibility. Gilley (2002) and Tømte (2008) reported that the usage, awareness and comfort levels of these technologies show variations among female and male teachers in spite of the widely accepted benefits of such technologies. Thus, it is imperative to examine whether the variations among female and male teachers still exist about the incorporation of technology in education. Most of the early studies revealed that computer experience played a role in narrowing the gender gap while other studies indicated that such experience might be gender-based. Todman (2000), for example, found that the reduction in computer anxiety for males was more apparent over time than in the case of females. Similarly, Umar and Yusoff (2014) found that male teachers use ICT in the classroom significantly more frequent than their female colleagues for teaching and learning as well as for creating presentation/delivery materials.

Kay (2007) stated that for the past 25 years, persistent gender differences in computer attitudes, ability, and use have been observed. These observations indicated that males (age 18 and older) have the advantage over females. More recent studies indicated that these results also apply to students in Grades 5 through 8, but there are strategies to help teachers address these gender differences. According to the author's extensive report of what works, Kay (2007) summarized a number of research studies on computer use by gender. He outlined the following points based on the results of numerous studies: (a) boys use computers more frequently than girls at their homes, their friends' homes, summer camps, and after-school clubs; (b) boys use computers to play games, use educational software, and access the Internet, whereas girls use computers for email, instant messaging, and homework; ( c) boys tend to be more assertive and dominant about computer use and girls tend to be more passive; (d) teachers cause girls to give up more easily than boys when solving computer-related problems; (e ) 
Almekhlafi, A. G., Ismail, S. A., \& Al-Mekhlafy, M. H.

girls appear to prefer to use computers for goal-oriented activities with meaningful contexts; (f) girls like co-operative learning based on inquiry and diversity of topics.

In summary, it is clear that the issue of integrating technology into education and differences between male and female teachers' perceptions of their technology integration is not clear-cut. Some studies documented significant differences between males and females while other studies documented the absence of such difference.

According to Top, Yukselturk, and Cakir (2011) there is a growing interest in the impact of gender differences in relation to the use of new technologies in education. This increasing attention indicates that gender differences are seen as an important research topic. Hence, the current study is conducted in order to investigate the issue in more depth within the context of the United Arab Emirates schools. It fills a gap in the literature in the sense that it covers a shortage in research in the United Arab Emirates and in the region. To guide the research process, four questions were formulated.

\subsection{Research questions}

Are there any significant differences between male and female language teachers' views regarding their utilization of technology?

$>$ Are there any significant differences between male and female language teachers' perceptions of technology integration barriers?

$>$ Are there any significant differences between male and female language teachers' views regarding the integration of different types of technology in their classes?

$>$ Are there any significant differences between male and female language teachers' perceptions regarding the employment of technology in promoting language teaching and learning environment?

\section{Method}

This study used both quantitative and qualitative methods for data collection. The questionnaire, featuring 5 Likert-scale items, represents the quantitative aspect of this research and the focus group interviews represent the qualitative aspect of the study. The questionnaire allowed for collecting quantitative data from a large number of participants, while the focus group interviews gave in-depth views of the interviewed participants.

\subsection{Participants}

The population of this study included male and female Arabic and English language teachers from the emirate of Abu-Dhabi's elementary schools (first cycle of basic education). The questionnaire was distributed randomly in both male and female schools to volunteering Arabic and English teachers. The total numbers of questionnaires collected were 431. Those teachers are both national and expatriate teachers from different countries and different cultural and educational backgrounds. The vast majority of them were native Arabic speakers while the rest of them were English native speakers. Very few came from other language backgrounds.

\subsection{Instruments}

Two instruments were employed to serve the objectives of this study in collecting the required data (a questionnaire and focus group interviews). The questionnaire was the first main tool for collecting the quantitative data from the participants. The validity of the two instruments was established by a panel of university professors specializing in education, senior school teachers and supervisors. They were asked to check whether the statements in the instrument clearly stated and appropriately aligned with the study problem and/or objectives. The judges suggested few corrections and/or modifications for some items and rephrasing for others. 
Male and female language teachers' technology integration differences in elementary schools in the UAE

All suggestions and comments of the jurors were taken into consideration when the final versions of the two instruments were produced.

The questionnaire consisted of four themes pertaining to instructional technology that male and female teachers use, namely utilization of technology, technology integration barriers, integration of different types of technology in classes, and the employment of technology in promoting language teaching and learning environment. A five-point Likert scale extending from 5 (very high or strongly agree) to 1 (very low or strongly disagree) was used in this questionnaire. The reliability of the questionnaire was calculated using Cronbach alpha. It was found to be 0.93 , which is considered very high. The reliability of the focus-group interviews was achieved via videotaping or audiotaping the participants to allow for reviewing participants' records; it was achieved via repeating the transcription of $50 \%$ of these records after 3 weeks that revealed $94 \%$ of agreements. The focus-group interviews included questions related to the four main themes of the questionnaire to get in-depth views about the issues included. Male participants were videotaped, while female participants were audiotaped for cultural reasons. Assistant researchers helped in the transcription of those interviews.

\subsection{Limitations of the study}

The scope of this study is limited to the perceptions of a sample of male and female teachers who were teaching in the Emirate of Abu Dhabi elementary schools. It is also limited to four areas of technology integration in teaching and learning activities as reflected in the questions of the studies.

\subsection{Procedures}

Research assistants were employed to help in collecting, keeping and managing the data. After attending two workshops and several meetings, two research assistants were asked to distribute the questionnaire in 25 elementary schools. All male and female teachers who were available during the research assistants' visit were requested to complete the survey. The response rate was about $75 \%$ of the distributed questionnaires. The three researchers conducted most of the interviews, while the research assistants only helped in doing a few interviews along with one of the researchers.

\subsection{Data analysis}

SPSS (Statistical Package for Social Sciences) was used to analyze the quantitative data. Descriptive statistics and independent samples t-tests were run to investigate the significant differences between male and female teachers' perceptions regarding technology integration in teaching first and second language. The qualitative data were only used to support the results collected from the questionnaires. For the purpose of management and analysis, the researchers organize and categorize all the qualitative data into themes and/or patterns. Later, they only extracted and/or focused on the recurrent patterns of the teachers' views.

\section{Results and discussions}

To answer question number 1 (Are there any significant differences between male and female teachers' views regarding their utilization of technology?), the independent samples t-test results highlighted very few differences between male and female teachers (see Table 1). In some cases, the differences were in favor of male teachers, while in other cases, they were in favor of female language teachers. The mean score for female teachers were significantly higher than the mean of male teachers in three areas; namely "Discussion of technology use, safety and health issues", "Using computers to assist students with special needs", and "Using computer applications that enhance students' reading ability" (see table 1). This might indicate that female teachers are concerned about safety issues more than their male counterparts are and they are more interested in special needs students and program to help improve students' reading ability. During the focus group interviews both male and female language teachers pointed out that technology helps them in catering for various students with different needs, abilities, learning styles, etc. A female English teacher singled out the importance of using 
Almekhlafi, A. G., Ismail, S. A., \& Al-Mekhlafy, M. H.

technology to assist students with special needs. She said,

I always use computers to help two students in my class. These students cannot read or write. I

use picture stories and other supporting materials to motivate them learn the new words.

On the other hand, the results showed that the mean scores for male teachers are significantly higher than those mean scores of female teachers in "Using word processing programs", and "Using spreadsheets such as MS Excel". Furthermore, the findings demonstrate a lot of common technology integration between male and female teachers. Both use technologies for a number of teaching and learning activities inside and outside the classroom, such as creating handouts, searching for information, and creating multimedia.

These inconsistent differences between male and female teachers, which are sometimes in favor of males and at some other times in favor of females, conform to many of the previous studies within the literature (Ray, Sormunen\& Harris, 1999; Houtz \& Gupta, 2001; Yuen \& Ma, 2002; Astrid, 2002; Gibbs \& Bernas, 2010; Top, Yukselturk \& Cakir, 2011). An overall analysis of the focus group interviews showed that both male and female teachers consider integrating technology into their teaching is crucial and an important for the success of their teaching and students' learning. The interviews indicated that teachers use technology tools and equipment differently depending on their area of specializations and interests.

During one of the focus group interviews, a number of male and female teachers highlighted the importance of using technology in their classes. They agreed that technology has become an integral part of their everyday teaching. A male English teacher said that he does not believe any teachers these days can survive in their job without decent knowledge of technology. He also mentioned that in language classes, teachers always need to use technology such as tools to provide students with opportunities to listen to native speakers.

\section{Table 1}

Differences between male and female teachers' views regarding their utilization of technology

\begin{tabular}{lccc}
\hline \multicolumn{1}{c}{ Variable } & Male mean & Female mean & $t$ \\
\hline Discussion of technology use safety and health issues & 3.9 & 4.1 & $-2.1^{*}$ \\
Using computers to assist students with special needs & 3.5 & 3.8 & $-2.8^{* *}$ \\
Using Word processing programs & 4.3 & 4.0 & $3.1^{* *}$ \\
Using spreadsheets (e.g., MS Excel) & 4.4 & 4.1 & $-4^{* *}$ \\
Using computer applications that enhance students' reading ability & 4.3 & 4.4 & $-2.0^{*}$ \\
Using language teaching-and-learning computer programs & 4.4 & 4.5 & -1.1 \\
Using technology to get and assess information & 4.5 & -0.4 \\
Using technology for data presentation and analysis & 4.2 & 4.1 & 1.9 \\
Using distance learning hardware and software & 3.7 & 3.7 & 0.6 \\
Using computers for creating databases & 4.0 & 3.8 & 1.8 \\
Using computers for on-line communication (e.g., e-mail). & 4.4 & 4.4 & 0.5 \\
Using adaptive \& assistive devices for special needs students & 3.7 & 3.7 & -0.4 \\
Using computers and appropriate technology terminology & 4.2 & 4.2 & -0.1 \\
Using a variety of devices such as scanners and cameras & 4.2 & 4.2 & -0.7 \\
Using computers to assess students' learning & 4.1 & 4.2 & -1.2 \\
Creating multimedia presentations (e.g., PPT presentations) & 4.5 & 4.6 & -1.5 \\
Operating a computer using a variety of software packages & 4.4 & 4.5 & -1.6 \\
Designing web sites & & 3.3 & 1.2 \\
Producing technology-based materials such as brochures & 4.3 & 4.3 & -0.5 \\
Integrating language labs to enhance students' learning & 4.2 & -0.2 \\
Integrating technology to enhance students' learning & & 4.4 & 0.3 \\
\hline
\end{tabular}

Note. $p<0.05$ 
Male and female language teachers' technology integration differences in elementary schools in the UAE

To answer question 2 (are there any significant differences between male and female teachers' perceptions of technology integration barriers?), the results show that both male and female teachers see a number of barriers that prevent them from technology integration such as lack of time to implement technology, lack of equipment and language labs, and lack of teachers' training needed for successful technology integration (see Table 2). However, male and female teachers perceived these barriers differently. The results showed a number of significant differences between male and female teachers in their perceptions of most of the barriers. Female teachers' mean scores were significantly higher than male teachers' mean scores on most of the variables investigated. This might indicate that female teachers use technology more than male teachers as some studies indicated (Ray, Sormunen \& Harris, 1999), and hence feel the existence of technology integration barriers more than male teachers do.

This is also in alignment with Hong and Koh (2002), in which they found female teachers are more anxious than male teachers pertaining to hardware. On the other hand, the results of this question do not match with results of some previous studies (Astrid, 2002; Ilie et al., 2005) where males were found to have greater perceptions of computers as well as greater confidence in their own success than female teachers. These results were confirmed by the focus group interviews pertaining to the existence of technology integration barriers. The results showed both males and females considered a number of barriers as obstructions to technology integration. Both indicated that time, lack of equipment, administration support, and professional development support and training are major obstacles to their successful and effective integration of technology. A female Arabic teacher highlighted the importance of the support of the administration in the school by saying:

We cannot employ technology, such as computers, unless we get support and encouragement from the school administration. They should look at our problems and help us find solutions to them.

Table 2

Differences between male and female teachers' perceptions of technology integration barriers

\begin{tabular}{lccc}
\hline \multicolumn{1}{c}{ Variables } & Male mean & Female mean & $t$ \\
\hline The curricula are not ready to use such new technologies & 2.9 & 3.4 & $-4.7^{* *}$ \\
Lack of time to prepare and implement technology & 3.6 & 4.2 & $-5.4^{* *}$ \\
Lack of technology resources in schools & 2.8 & 3.6 & $-7.0^{* *}$ \\
Lack of labs and their equipment & 3.0 & 3.6 & $-5.1^{* *}$ \\
Lack of availability of labs' qualified staff & 2.8 & 3.2 & $-3.9^{* *}$ \\
Lack of technologies needed for teaching languages & 3.0 & 3.5 & $-4.8^{* *}$ \\
Lack of equipment and technology maintenance & 3.0 & 3.2 & $-2.1^{*}$ \\
Lack of encouragement to use new technologies & 2.8 & 3.1 & $-2.1^{*}$ \\
Lack of teacher training workshops & 3.1 & 3.3 & -1.6 \\
Lack of students' desire for technology integration & 2.7 & 2.9 & -1.8 \\
Lack of knowledge and skills in technology integration & 2.3 & 2.3 & -0.3 \\
\hline
\end{tabular}

To answer question number 3 (Are there any significant differences between male and female teachers' views in integrating technology in their classes?), the results showed a number of significant differences between male and female teachers (see Table 3). Pertaining to using videotapes, audiotapes, OHP and opaque projectors, TVs, and obtaining resources from the local environment, female teachers' mean scores were significantly higher than those mean scores of male teachers. This means that the usage of technology by female teachers is different from male teachers' usage. It seems that females use technology more than males, particularly the use of audio-visual aids such as audio and video tapes.

On the other hand, male teachers' mean scores on using email, and distance education training were higher than the female teachers' mean scores. This could mean that male teachers use communication tools such as 
Almekhlafi, A. G., Ismail, S. A., \& Al-Mekhlafy, M. H.

email more than female teachers. These differences are in alignment with previous similar studies that investigate male-female technology integration and perception differences (Yuen \& Ma, 2002; Astrid, 2002; Tømte, 2008; Gibbs \& Bernas, 2010; Top, Yukselturk \& Cakir, 2011).

In spite of these differences between male and female teachers, the focus group interviews' results indicated that all teachers highly regard incentives as a motivator to their continual use of information and communication technology. Both male and female teachers agreed and suggested that teachers who are continuously using technology should be given incentives in order to encourage other teachers to integrate technology in their classes. One of the English female teachers highlighted this issue by saying:

Teachers will continue integrating technology in teaching English if they are encouraged by the administration at schools. I think other teachers will also use technology in their classes if incentives are given to those teachers who are using it today.

This quotation highlights the importance of supports and/or rewards to encourage and convince all teachers to continue the integration of technology in teaching and learning. It also indicates that some teachers may get disappointed if their extra effort in integrating technology is not properly acknowledged and/or appreciated by administrators.

Table 3

Differences between male \& female teachers' views regarding the integration of different types of technology

\begin{tabular}{lccc}
\hline \multicolumn{1}{c}{ Questions } & Male mean & Female mean & $t$ \\
\hline Video tapes & 3.7 & 4.1 & $-4.3^{* *}$ \\
Over Head and Opaque Projectors & 4.1 & 4.5 & $-5.9^{* *}$ \\
TV & 3.6 & 4.0 & $-4.4^{* *}$ \\
Email & 3.9 & 3.5 & $3.3^{* *}$ \\
Distance education training sessions & 3.8 & 3.6 & $2.2^{*}$ \\
Resources from local environment & 4.0 & 4.2 & $-2.5^{*}$ \\
Audio tapes & 4.2 & 4.3 & $-2.1^{*}$ \\
Dictionaries and encyclopedias & 4.0 & 3.9 & 1.1 \\
Language labs & 3.6 & 3.6 & 0.0 \\
Electronic forums & 3.7 & 3.6 & -1.1 \\
Smart and interactive boards & 3.5 & 3.7 & 0.0 \\
Chat rooms and discussion boards & 3.4 & 3.4 & 0.1 \\
Newsgroups & 3.5 & 3.6 & -0.2 \\
Language teaching programs & 4.2 & 4.1 & 0.6 \\
World Wide Web (www) & 4.3 & 4.2 & 1.3 \\
\hline
\end{tabular}

To answer question number 4 (Are there any significant differences between male and female teachers' perceptions regarding the employment of technology in promoting language teaching and learning environment?), the results showed that both male and female teachers had high perceptions regarding the employment of technology (see Table 4). All mean scores for both male and female teachers were above 4.0 on a 5 -point scale extending from 5 (extremely high) to 1 (extremely low) on all investigated variables. This means that all teachers regardless of gender perceive technology as a tool that can promote language teaching and learning environment. They perceive technology as a medium that can assist in creating an attractive teaching and learning environment, improve students' language skills and academic achievement, support active learning and teaching strategies, and provide opportunities that help autonomous learning. This is similar to previous studies that did not highlight any significant differences between male and female teachers pertaining to the use of technology in teaching such as Smith (1986); Gattiker \& Hlavka (1992); and Ismail, Almekhlafi, and Almekhlafy (2010). 
Male and female language teachers' technology integration differences in elementary schools in the UAE

Data collected via the focus group interviews showed that some English language female teachers indicated that their technology competencies have developed a lot based on the intensive use of technology in their classes. Similarly, Arabic female teachers indicated that in order to make an optimal use of technology in teaching languages, they need more training in order to become more competent in using different software for teaching languages. One of them said:

I can use computers in my classes for different purposes, such as doing a PowerPoint presentation to explain some grammatical points in Arabic, but this is not enough. I feel I need to learn to use more programs in order to employ them in my teaching”.

Table 4

Differences between male and female teachers' perceptions regarding the employment of technology in promoting language teaching and learning environment

\begin{tabular}{|c|c|c|c|}
\hline Questions & $\begin{array}{l}\text { Male } \\
\text { mean }\end{array}$ & $\begin{array}{c}\text { Female } \\
\text { mean }\end{array}$ & $t$ \\
\hline \multicolumn{4}{|l|}{ Technology helps } \\
\hline students understand languages & 4.3 & 4.2 & -0.7 \\
\hline create active learning during language classes & 4.4 & 4.4 & -0.1 \\
\hline improve students' language skills and knowledge & 4.4 & 4.3 & -0.6 \\
\hline in integrating different language activities & 4.4 & 4.2 & 1.5 \\
\hline in promoting cooperative activities in the classroom & 4.2 & 4.4 & -0.4 \\
\hline in evaluating classroom activities & 4.5 & 4.4 & 1.5 \\
\hline students meet their language needs in the classroom & 4.2 & 4.3 & -0.7 \\
\hline \multicolumn{4}{|l|}{ Technology assists in } \\
\hline developing electronic exams & 4.2 & 4.5 & 0.5 \\
\hline supporting project activities and problem-solving. & 4.1 & 4.3 & 0.4 \\
\hline improving students' academic achievement and grades & 4.2 & 4.5 & -1.5 \\
\hline improving students' language proficiency level & 4.2 & 4.5 & 0.2 \\
\hline improving students' motivation & 4.4 & 4.4 & -1.6 \\
\hline \multicolumn{4}{|l|}{ Technology provides } \\
\hline opportunities for different language learning strategies & 4.3 & 4.2 & -1.0 \\
\hline students with tools for using electronic dictionaries & 4.4 & 4.2 & 1.1 \\
\hline opportunities that promote autonomous learning. & 4.2 & 4.2 & -1.5 \\
\hline
\end{tabular}

\section{Conclusion and recommendations}

This study generally examined male and female Arabic and English language teachers' views regarding the utilization of technology in teaching first and second language in the UAE. It highlighted a number of issues pertaining to the differences between male and female teachers' perceptions about integration of technology in the United Arab Emirates elementary schools. The results of some items demonstrated that male teachers exceeded female teachers in technology integration strategies, while the results of other items showed that female teachers exceeded male teachers. Many other items' results did not display any significant differences between male and female teachers in the integration of technology.

These results are to some extent in agreement with past research studies investigating such differences. The researchers recommend that educators should continue to intensify the use of appropriate technology to improve students' learning outcomes. When planning and designing curricula, it is very crucial to make technology not as a supplementary aid to the curriculum, but it should be made as an integral part of any future curriculum. Another recommendation is to conduct in depth studies investigating male and female differences using qualitative data collection methods. Other studies might be carried out to explore teachers' beliefs and actual 
Almekhlafi, A. G., Ismail, S. A., \& Al-Mekhlafy, M. H.

technology use in the classroom.

The results of the study might give insights to decision makers, teacher trainers, stakeholders, classroom teachers, and other educators on the use of technology and its impact on teaching and learning. Based on the results of this study, male and female teachers and students alike might try to take an advantage of technology when teaching or learning languages.

\section{References}

Almekhlafi, A. G., \& Almeqdadi, F. A. (2010). Teachers' perceptions of technology integration in the United Arab Emirates school classrooms. Educational Technology \& Society, 13(1), 165-175.

Astrid, M. S. (2002). Gender differences in computer-related control beliefs and home computer use. Scandinavian Journal of Educational Research, 46(4), 409-426. http://dx.doi.org/10.1080/0031383022000024589

Badia, A., Menesesa, J., Sigalésa, C., \& Fàbregues, S. (2014). Factors affecting school teachers' perceptions of the instructional benefits of digital technology. Procedia - Social and Behavioral Sciences, 141(2014) 357-362. http://dx.doi.org/10.1016/j.sbspro.2014.05.063

Bakr, S. (2011). Attitudes of Egyptian teachers towards computers. Contemporary Educational Technology, 2(4), 308-318.

Banas, J. (2010). Teachers' attitudes toward technology: Considerations for designing preservice and practicing teacher instruction. Community \& Junior College Libraries, 2, 114-127. http://dx.doi.org/10.1080/02763911003707552

Bitner, N., \& Bitner, J. (2002). Integrating technology into the classroom: Eight keys to success. Journal of Technology and Teacher Education, 10, 95-100.

Broos, A. (2005). Gender and information and communication technologies (IT) anxiety: Male self-assurance and female hesitation. Cyber Psychology \& Behavior, 8(1), 21-31. http://dx.doi.org/10.1089/cpb.2005.8.21

Frigaard, A. (2002). Does the computer lab improve student performance on vocabulary, grammar, and listening comprehension? ERIC Document Reproduction Service No. ED476749.

Gattiker, U., \& Hlavka, A. (1992). Computer attitudes and learning performance: Issues for management education and training. Journal of Organizational Behavior, 13, 89-101. http://dx.doi.org/10.1002/job.4030130109

Gibbs, W. J., \& Bernas, R. S. (2010). Gender differences in online communication of teacher preparation students. In Yamamoto, J., Penny, C., Leight, J., \& Winterton, S. (Eds.), Technology leadership in teacher education: Integrated solutions and experiences (pp. 45-66). Hershey, PA: IGI Global. http://dx.doi.org/10.4018/978-1-61520-899-9.ch004

Gilley, J. (2002). Gender and technology awareness training in preservice teacher education. TechTrends, 46(6), 21-26. http://dx.doi.org/10.1007/BF02824156

Hong, K., \& Koh, C. (2002). Computer anxiety and attitudes toward computers among rural secondary school teachers: A Malaysian perspective. Journal of Research on Technology in Education, 35(1), 27-46. http://dx.doi.org/10.1080/15391523.2002.10782368

Houtz, S., \& Gupta, P. (2001). Gender roles, computer attitudes, and dyadic computer interaction performance among teacher educators. Journal of Organizational Behavior, 20(3), 1-9.

Hüseyin, Ö. Z. (2014). Teachers' and students' perceptions of interactive whiteboards in the English as a foreign language classroom. TOJET: The Turkish Online Journal of Educational Technology, 13(3), 156-177.

Ilie, V., Van Slyke, C., Green, G., \& Hao, L. (2005). Gender differences in perceptions and use of communication technologies: A diffusion of innovation approach. Information Resources Management Journal, 18(3), 13-31. http://dx.doi.org/10.4018/irmj.2005070102

Ismail, S. A., Almekhlafi, A. G., \& Al-Mekhlafy, M. H. (2010). Teachers' perceptions of the use of technology in teaching languages in United Arab Emirates' schools. International Journal for Research in 
Male and female language teachers' technology integration differences in elementary schools in the UAE

Education, 27(1), 37-56.

Johnson, N. (2006). Boys and girls are the same: Gender perceptions in using computers in the classroom. Computers in New Zealand Schools, 18(3), 5-11.

Kanthawongs, P., \& Kanthawongs, P. (2013). Perception of primary school students, parents and teachers toward the use of computers, the internet and social networking sites. Procedia-Social and Behavioral Sciences, 88, 282-290. http://dx.doi.org/10.1016/j.sbspro.2013.08.507

Karaca, F; Can, G., \&Yildirim, S. (2013). A path model for technology integration into elementary school settings in Turkey. Computers \& Education, 68, 353-365. http://dx.doi.org/10.1016/j.compedu.2013.05.017

Kavanoz, S., Yüksel, H., \& Ozcan, E. (2015). Pre-service teachers' self- efficacy perceptions on web pedagogical content knowledge. Computers \& Education, 85, 94-101. http://dx.doi.org/10.1016/j.compedu.2015.02.005

Kay, R. (2007). Gender differences in computer attitudes, ability, and use in the elementary classroom. Retrieved from http://www.edu.gov.on.ca/eng/literacynumeracy/inspire/research/Kay.pdf

Kobak, M., \& Taskin, N. (2012). Prospective teachers' perceptions of using technology. Procedia - Social and Behavioral Sciences, 46, 3629-3636. http://dx.doi.org/10.1016/i.sbspro.2012.06.118

Korumaz, M., \& Karabiyik, B. (2014). Effects of teachers' self-efficacy perception on computer assisted teaching perception. Social and Behavioral Sciences, 116, 2243-2247. http://dx.doi.org/10.1016/j.sbspro.2014.01.552

Kumar, N., Che Rose, R., \& D'Silva, J. L. (2008). Factors influencing the effective use of technology among Malaysian teachers. European Journal of Social Sciences, 6(4), 108-125.

Lee, V. E. (1997). Effects of high school restructuring and size on early gains in achievement and engagement. Sociology of Education, 68, 241-270. http://dx.doi.org/10.2307/2112741

Martina, R. M., Meelissen, M. R., \& Drent, M. (2008). Gender differences in computer attitudes: Does the school matter? Computers in Human Behavior, 24, 969-985. http://dx.doi.org/10.1016/j.chb.2007.03.001

Mehloff, C. E. (2001). Knowledge, commitment and attitudes of home economics faculty towards computer. Home Economic Research Journal, 17(4), 300-308. http://dx.doi.org/10.1177/1077727X8901700403

Nikian, S., Nor, F. M., \& Aziz, M. A. (2013). Malaysian teachers' perception of applying technology in the classroom. Procedia-Social and Behavioral Sciences, 103, 621-627. http://dx.doi.org/10.1016/j.sbspro.2013.10.380

Onwuagboke, B. B. C., \& Singh, T. K. R. (2016). Faculty attitude and use of ICT in instructional delivery in tertiary institutions in a developing nation. International Journal of Research Studies in Educational Technology, 5(1), 77-88.

Ozer, N., Ugurlu, C. T., \& Beycioglu, K. (2011). Computer teachers' attitudes toward ethical use of computers in elementary schools. International Journal of Cyber Ethics in Education, 1(2), 15-24. http://dx.doi.org/10.4018/ijcee.2011040102

Rafieea, S. J., \& Purfallah, S. A. (2014). Perceptions of junior high school teachers toward computer assisted language learning (CALL) within the context of Azarbayjan Provinces. Procedia - Social and Behavioral Sciences, 98, 1445 - 1453. http://dx.doi.org/10.1016/j.sbspro.2014.03.564

Ray, C., Sormunen, C., \& Harris, T. (1999). Men's and women's attitudes toward computer technology: A comparison. Office Systems Research Journal, 17(1), 1-8.

Razavi, A., Ghanizadeh, A., \& Akbari, O. (2016). Teachers' perceptions of the use of multimedia in teaching English in official and non-official language learning settings. International Journal of Research Studies in Educational Technology, 5(1), 91-104.

Roblyer, M. D., \& Davis, L. (2008, Winter). Predicting success for virtual school students: Putting research-based models into practice. Online Journal of Distance Learning Administration, XI(IV). Retrieved from http://www.westga.edu/ distance/ojdla/winter114/roblyer114.html

Saqlain, N., Al-Qarni, F., \&Ghadi, N. (2013). Are English language teachers in Saudi Arabia ready to integrate technology? Procedia-Social and Behavioral Sciences, 103, 146-153. 
Almekhlafi, A. G., Ismail, S. A., \& Al-Mekhlafy, M. H.

http://dx.doi.org/10.1016/j.sbspro.2013.10.319

Schofield, J. W., \& Davidson, A. (2003). The impact of internet use on relationships between teachers and students. Mind, Culture and Activity, 10, 62-79. http://dx.doi.org/10.1207/S15327884MCA1001_06

Sia, P. W. (2000). Computer anxiety and computer literacy among urban secondary school teachers in Miri (Unpublished masteral thesis). Kota Samarahan: University Malaysia of Sarawak.

Smith, S. (1986). Relationships to computer attitudes to sex, grade level, and teacher influence. Education, 106, 338-344.

Thang, S. M., Lee, K. W., Murugaiah, P., Jaafar, N. M., Tan, C. K., \& Bukhari, N. I. A. (2016). ICT tools patterns of use among Malaysian ESL undergraduates. GEMA Online Journal of Language Studies, 16(1), 49-65.

Timucin, M. (2006). Implementing CALL in the EFL context. ELT Journal, 60(3), 262-271. http://dx.doi.org/10.1093/elt/ccl006

Todman J. (2000). Gender differences in computer anxiety among university entrants since 1992. Computers and Education, 34(1), 27-35. http://dx.doi.org/10.1016/S0360-1315(99)00036-6

Tømte, C. (2008). Return to gender: Gender, ICT and education. Background paper for the OECD Expert meeting hosted by the Norwegian Ministry of Education and Research, Oslo, Norway.

Top, E., Yukselturk, E., \& Cakir, R. (2011). Gender and Web 2.0 technology awareness among ICT teachers. British Journal of Educational Technology, 42(5), E106-E10. http://dx.doi.org/10.1111/j.1467-8535.2011.01208.x

Umar, I. N., \& Yusoff, M. T. M. (2014). A study on Malaysian teachers' level of ICT skills and practices, and its impact on teaching and learning. Procedia-Social and Behavioral Sciences, 116, 979-984. http://dx.doi.org/10.1016/j.sbspro.2014.01.331

Venkatesh, V. \& Morris, M. G. (2000). Why do not men ever stop to ask for directions? Gender, social influence, and their role in technology acceptance and usage behavior. MIS Quarterly, 24(1), 115-139. http://dx.doi.org/10.2307/3250981

Wong, S. L., \& Hanafi, A. (2007). Gender differences in attitudes towards information technology among Malaysian student teachers: A case study at Universiti Putra Malaysia. Educational Technology \& Society, 10(2), 158-169.

Woodrow, J. E. J. (1991). A comparison of four computer attitude scales. Journal of Educational Computing Research, 7(2), 165-187. http://dx.doi.org/10.2190/WLAM-P42V-12A3-4LLQ

Yastibas, A., \& Cepik, S. (2015). Teachers' attitudes toward the use of e-portfolios in speaking classes in English language teaching and learning. Procedia - Social and Behavioral Sciences, 176, 514-525. http://dx.doi.org/10.1016/j.sbspro.2015.01.505

Yuen, H. K., \& Ma, W. K. (2002). Gender differences in teacher computer acceptance. Journal of Technology and Teacher Education, 10(3), 365-382.

Yukselturk, E., \& Bulut, S. (2009). Gender differences in self-regulated online learning environment. Educational Technology \& Society, 12(3), 12-22.

Yungwei, H., \&Lee, K. (2015). Teachers' concern about integrating Web 2.0 technologies and its relationship with teacher characteristics. Computers in Human Behavior, 48, 1-8. http://dx.doi.org/10.1016/j.chb.2015.01.028 